\title{
A Catholic Reflects on Dialogue in the Abortion Debate
}

\section{Joseph Tham*}

School of Bioethics, Regina Apostolorum Pontifical University, Rome, Italy

\begin{abstract}
The recent comments by Pope Francis on abortion have caused a bit of a stir in the media. His nuanced responses are often lost in the media, and also by advocates on both sides of the abortion debate. While the Catholic position against abortion is common knowledge, this does not preclude openness to dialogue. This article looks at some recent attempts at dialogue on the controversial topic of abortion. The first example comes from a book that surveys the public view on abortion that surprisingly finds many areas of common ground. Followed by this is a theological reading of Pope Benedict's encyclical 'Charity in truth' that can be the basis of dialogue between parties with divergent views. A third example refers to a conference in Princeton University three years ago, where I mentioned several points where dialogue could be built.
\end{abstract}

Keywords: Abortion; Catholicism common ground; dialogue; Caritas in Veritate

\section{Introduction}

Recently comments by Pope Francis on abortion caused a media stir. During an interview with the Jesuit Magazine Civiltà Cattolica, Pope Francis made recommendations for how Catholics should broach the difficult subject:

We cannot insist only on issues related to abortion, gay marriage and the use of contraceptive methods. This is not possible. I have not spoken much about these things, and I was reprimanded for that. But when we speak about these issues, we have to talk about them in a context. The teaching of the church, for that matter, is clear and I am a son of the church, but it is not necessary to talk about these issues all the time [1].

The media was of two minds on this "new" approach. The liberal press saw this as a breath of fresh air from the previous (all too rigid) pronouncements of the popes, whereas the conservative press was shocked and dismayed at the news. However, the deeper meaning of the Pope's comments falls somewhere in between these opposing reactions. His deeper message seems to have been largely lost.

To start, most people have not read the published interview. Indeed, Pope Francis has not changed the Catholic teaching (which is in principle opposed to abortion), but merely they way we talk about it today. He believes the approach to the subject must be contextualized and pastorally oriented.

Unfortunately, such nuanced responses are often lost in the media, and by advocates on both sides of the abortion debate. While the Catholic position against abortion is common knowledge, less known is the Church's intellectual tradition to seek truth not as something already possessed, but as a journey. This is not relativism, rather, it is an openness to dialogue and a belief in the existence of truth that is accessible by reason.

The interview with Pope Francis demonstrates this element in his own Jesuit tradition, which calls for constant discernment of the spirit and to be in continual tension. His comments about the spiritual life can be illustrating:

Yes, in this quest to seek and find God in all things there is still an area of uncertainty. There must be. If a person says that he met God with total certainty and is not touched by a margin of uncertainty, then this is not good. For me, this is an important key. If one has the answers to all the questions - that is the proof that God is not with him. It means that he is a false prophet using religion for himself... The risk in seeking and finding God in all things, then, is the willingness to explain too much, to say with human certainty and arrogance: 'God is here.' We will find only a god that fits our measure [2].

This constant search for truth and dialogue with the world that Pope Francis spoke about is not exclusive to him. For instance, the Pontifical Council for Culture under the inspirations of Pope John Paul II and Pope Benedict XVI has promulgated the 'Courtyard of the Gentiles' project which has the goal of engaging the secular world and those who hold different views in a spirit of fraternity. It is based on a firm belief that as reasonable persons, there is always room for dialogue even though there can be disagreements [3].

In this spirit, I would like to mention some recent attempts at dialogue on the controversial topic of abortion. Dialogues are fruitful only if there is an openness to seek objective truth. The first example comes from a book that surveys the public view on abortion that surprisingly finds many areas of common ground. Then, I provide a theological reading of Pope Benedict's encyclical Caritas in veritate that can be the basis of dialogue between parties with divergent views. The last example refers to a conference in Princeton University three years ago, where I was a speaker. At that conference, I proposed several points where dialogue could be built on the three values of truth, love and freedom.

\section{Common Ground?}

A few years back, two Catholic authors, John Fleming and Nicholas Tonti-Filippini, wrote Common Ground? Seeking an Australian Consensus on Abortion and Sex Education [4]. As the interrogative of the title suggests, many agreements could surprisingly be shared between the pro-life and pro-choice camps. This book sought to highlight these potential common grounds based on empirical studies.

*Corresponding author: Joseph Tham, Adjunct Professor, School of Bioethics, Regina Apostolorum Pontifical university, Via degli Aldobrandeschi $190-00160$ Rome, Italy, Tel: (39) 06 66527654; (39) 3451052662; (1) 214-205-6042; (852) 64455832; Fax: (39) 06 66527814; E-mail: jtham@legionaries.org

Received November 19, 2013; Accepted December 28, 2013; Published January 02, 2014

Citation: Tham J (2014) A Catholic Reflects on Dialogue in the Abortion Debate. $J$ Clin Res Bioeth 5: 168. doi:10.4172/2155-9627.1000168

Copyright: () 2014 Tham J. This is an open-access article distributed under the terms of the Creative Commons Attribution License, which permits unrestricted use, distribution, and reproduction in any medium, provided the original author and source are credited. 
The most significant contribution to this collection of essays comes from the first three chapters by Fleming, based on detailed surveys analyzing the population's attitudes toward the complex subject of abortion. Even though the surveys are specific to Australia, it is most likely that the opinions and results garnered here could mirror those in North America and Europe.

In Australia, as in the US, there was never a public debate on abortion when it became decriminalized in different states over a period of time from 1968-2002. The authors lamented a sad absence of accurate statistics on the current practice of abortion in Australia. Curiously, there was also a lack of political will to find out the exact situation due to mutual mistrust, making the debate one that was more based on rhetoric rather than on hard facts [4].

According to the study, it appears that the Australian laws on abortion were often not reflective of the public opinion. As Fleming notes, "Much of the rhetoric used in the abortion debate consists of 'assertions' and 'personal beliefs' which those who hold them do not always submit to critical scrutiny." [5] In fact, much of the rhetoric used to support the status quo of abortion laws were not based on empirical facts. Some of these are, for example, the claim that deaths from unhygienic "backyard abortions" were the only alternatives to liberal abortion laws; that men should not have input in this debate which is a women's issue; and that if women were well informed on the use of contraceptives there would be less abortion.

The surveys revealed certain ambivalence in Australians' attitude toward abortion. On the one hand, a majority of those interviewed (75\%) believed that women have the right to choose to have an abortion. However, on further questioning, an equal percentage of the population was concerned with the immorality of this practice. This majority of $75 \%$ felt that the rate of abortion in the country then (one in four life births) was too high, was a mark of societal failure, and wanted to reduce the incidence of abortion if possible. They preferred in practice that the right to abortion not be exercised by women but as a last resort, that it would become a rare event, and that a wide range of initiatives would be available for pregnant women to make choices other than abortion.

Thus, the author concluded that the majority of Australians were curiously pro-choice and pro-life at the same time. They were prochoice in that many believed women should have the rights to abortion on demand without restrictive laws. But they were also pro-life in that they believed women should be given real alternatives to choose not to abort. This ambivalence was possibly a reflection of the uncertainty to the question on the personhood of the unborn. Only $45 \%$ of Australians thought that the fetus is a person.

A great consensus of $92 \%$ of those surveyed believed that all alternatives to abortion should be available to women so that they can make informed decisions. A large majority also supported laws that would make it illegal to coerce women to undergo abortions.

Since a majority of those surveyed desired that women contemplating abortion should be aware of all available alternatives, the next set of questions dealt with the amount and type of information they should receive. While there was a general agreement that informed consent should be obtained before women undergo abortion, there was disagreement about the amount and type of information they should get. Paradoxically, some people felt that one is less free when one has too much information. This request for more information was in conformity with the survey result that only $22 \%$ consider themselves well informed on the issue of abortion.
Since it was generally agreed that abortion rates should be lowered, the survey probed and discovered that there is a general consensus to provide greater education in homes and schools to prevent unwanted pregnancies. A majority of Australians (84\%) shared the view that sex education should have greater parental input and should therefore reflect family values. In addition, they were not too confident that current sex education given in schools would lower the abortion rates. At the same time, they were altogether ignorant of who is responsible for designing these sex education programs.

Since the surveys revealed that women contemplating abortion should make informed decisions so as to act with greater responsibility-adequately considered all alternatives and aware of the risks and consequences of the procedure-counseling was deemed a necessity. They felt that this service should be professional, nondirective, respecting the woman's right to make her own decisions, and independent especially from abortion providers [6]. As a result, $89 \%$ of those surveyed felt that physicians are most apt (and some would want this bound by law) to provide counseling and disclose risks factors related to the procedure, be they risks related to surgery, mental health or infertility. Doctors should also inform women of all available alternatives. A surprising percentage (59\%) advocates a cooling-off period of up to a week to gather information before the woman is allowed to undergo abortion. While it is generally felt that abortion counseling should not be provided by abortion clinics but an independent source, $60 \%$ could not name one other organization where this could be obtained.

In all, this study provides us a very interesting glimpse of the public opinion on abortion in one Western society. It is astonishing to note that many assumptions made by lawmakers on women's choice, men's participation, parental involvement for minors, and information disclosure were not in conformity with public opinion. Unfortunately, these nuances were often not known because of a paucity of research. Many similar studies in other countries and contexts would be needed to encourage a well informed and balanced discussion on abortion, a discussion that is not based on rhetoric and past ideologies but on societal consensus toward the most reasonable solutions.

\section{Charity in Truth}

The encyclical Caritas in Veritate by Pope Benedict XVI has been hailed as one of the most important papal documents on economic development which addresses the current financial crisis and its societal impact. Less known is the central thesis which claims that the universal acceptability of any ethical proposal must correspond to the two demands of truth and charity. And there we will find a constant tension at two levels, within truth itself and between truth and charity [7].

On the one hand, the Catholic Church epistemologically affirms the existence of universal truths that can be known and accessible to all persons, and rejects the thesis of relativism, be it cultural, philosophical or moral [8]. On the other hand, there is also a realistic recognition that this truth is less of a predetermined possession but rather a common goal of humanity. We must realize with humility that human knowledge is always "in progress" and thus "incomplete" due to human weaknesses (or theologically speaking, our intellect and will have been damaged by original sin) [9].

Charity also demands that we must approach truth not as an external imposition on others. While not denying the existence and universal accessibility of certain truths by means of reason, charity still requires 
that these truths be proposed and delivered to each individual with genuine respect in accordance to where he is at a given point, without violence or imposition. This is what Pope Francis meant when he said in the interview that the Church is like a field hospital after battle. Its task is to treat the seriously injured before treating his cholesterol or blood sugars problems [10]. Hence, the pastoral approach would entail that any moral truths (e.g. Church teaching on abortion) when explained to an individual must take into account of her mindset, history and circumstance. This is the pastoral approach, without diluting the moral truth, and as the true meaning of tolerance, is a balance between first loving the sinner and then not excusing the sin.

As Charles Camosy emphasized, the Catholic Social Teaching on solidarity must be extended to include "intellectual solidarity." By this, he means that charity demands that we treat those who share different views from ours with deference, respect and humility. It means a willingness to honest engagement on difficult subjects and areas of disagreement with intellectual camaraderie [11]. This is by no means easy. As Dan Callahan once commented, it is easier to pontificate from our respective castles, throwing thunderbolts at each other [12].

People tend to hang around with others who are like them-in terms of family ties, race, age, social class, education, taste, interests, etc. This is part of our natural tendency and sociability. We tend to feel more comfortable with those who are like-minded because we feel we are in control of the situation. We are afraid of the unknown in human relationships. When we encounter someone who acts strangely, who is mentally ill, or a group different from us (e.g., foreigners, punks, gangsters, etc.) our immediate reaction is to withdraw and distrust. The same can be true in the realms of religious, ideological and political convictions. Pro-lifers tend to hang around with those who agree with them, and the same for pro-choice groups. This may be because we find it tiresome and uncomfortable to argue or engage others with drastically opposite views. It may be easier to paint the world in black and white and demonize the oppositions. Talking with the opponents may appear as a sell out to her cause.

In some way, this is due to the fact that normally our identity is wrapped up in our ideals, our religion, and our convictions. We feel secure when we surround ourselves with those who are similar to us, and our identity may be threatened when confronted with others who are different. In today's metropolis marked by pluralism and relativism, our sense of identity and security are often fragile. This need for reassurance by rejecting the different "other" can be manifested in several ways. First, is a form of fundamentalism or traditionalism, where he hangs on to a certain idea or ideal and considers anyone who differs as threats and enemies. Hence, religious fundamentalism can sometimes fall prey into terrorism (e.g. 9-11). Similarly, pro-life activism can mistakenly resort to violence by attacking abortion providers. Pope Francis comments on the danger of this rigid hold onto the past even among religious persons:

If the Christian is a restorationist, a legalist, if he wants everything clear and safe, then he will find nothing. Tradition and memory of the past must help us to have the courage to open up new areas to God. Those who today always look for disciplinarian solutions, those who long for an exaggerated doctrinal 'security', those who stubbornly try to recover a past that no longer exists-they have a static and inwarddirected view of things. In this way, faith becomes an ideology among other ideologies [13].

The second reaction against the threat to identity could take the form of relativism where she resigns herself to the reality of plurality and difference to the extent that negates the existence of any constant and stable truths. The modern "virtue" of tolerance is taken to mean that all differences are equally valid choices, and should be respected. This too can degenerate into "intolerant tolerance," especially against those who believes in certain perennial truths and values [14].

Both positions have inherent contradictions, as protest against violence against the innocent unborn itself turn violent, and exaltation of tolerance becomes itself intolerant. Violence is a result of the failure to dialogue. That is why intellectual solidarity, or charity in dialoguing with those who differ, is so important in the modern world.

This idea of dialogue in public debates is not exclusive to Catholic thought. Anglican moral theologian Nigel Biggar also sees a via media between the two extremes of fundamentalism and liberal relativism by what he called Barthian Thomism. He believes that true Christians engaged in public ethics must do so with openness, honesty, humility and charity, recognizing that we are sinners but also called to be prophetic:

Impelled by their own theological convictions, Christians will recognize their non-Christian interlocutors to be not just sinners but fellow sinners... Accordingly, Christians will lay aside stereotypes and caricatures and resolve instead to find out what is actually there. They will approach others with a humble readiness to learn as well as to teach, and with an openness to discerning consensus, however fragmentary, provisional and tense it may be. Keeping their evangelical talk from mere rhetoric, they will let its manner be discipline by its content. Adopting humility, docility, patience, forbearance, forgiveness-as well as candid truthfulness-they will learn to love in conversation and thus to behave in public deliberation [15].

Dialogue is the new language of peace in the modern world. This is ever so true in interreligious dialogue. I learnt from this experience when I encountered people from other cultural and religious traditions. The initial sensation of discomfort and threat was very real. I initially felt threatened by them because their conviction could undermine my own. The temptation to totally reject the other as heretical or pagan is very real. There is a fear that by accepting them into my circles, I would possibly bend towards cultural and moral relativism [16].

In this regard, the insights of Alasdair MacIntyre on "traditionconstituted" moral inquiry are very helpful [17]. He purports that when speaking of moral traditions like Aristotelian, Confucian, Buddhist, Hindu, etc. that are so different that they are incommensurable-there is no neutral ground where he is exterior to these traditions where he can judge the superiority of one over the other. Yet, for MacIntyre this incommensurability does not lead to relativism, "Incommensurability, it turns out, does not preclude rational debate and encounter" [18]. To enter the conversation, what is required-other than being sufficiently fluent in the languages of both traditions-is that the inquirer must be fully immersed in his own culture and history in order to accurately represent it. The second stage involves the more serious task when inquirers of one moral tradition write the history of the rival moral tradition from that rival tradition's point of view, "employing the standards of rational success or failure internal to that other's point of view" [18]. He must be prepared to expose his own tradition with intellectual honesty and "maximal vulnerability" without hiding defects. In this sincere conversation, such exchanges and comparisons would allow the rival traditions to see their weaknesses and strengths, and rationally recognize their own incoherence and the superiority of their rival, with the possibility of abandonment of their own tradition.

In the case of the abortion debate in the West, it is the Christian 
traditions at odds with the liberal tradition. These two traditions have a common roots and a similar language, so one cannot speak of incommensurability to the same extent. Hence, it is hopeful that such an engagement can possibly result in the less coherent and reasonable moral tradition yielding to the superior and more consistent one.

\section{Open heart, open mind and fair minded words: The Princeton conference}

Several years ago, Princeton University held a conference entitled "Open hearts, open minds and fair minded words in the abortion debate" [19]. It was an attempt to bring together people from all sides of the abortion issue. Five hundred persons attended the event coming from pro-life, pro-choice and self-described middle ground positions. The speakers also came from diverse walks of life. Interestingly, three of the organizers were Catholics (Francis Kissling, Charlie Camosy, and Jennifer Miller), and one atheist (Peter Singer). I was one of the few clerics invited to speak. The panel which I was asked to speak on was on the use of contraceptives as a means to prevent abortions. I was mildly surprised when Francis Kissling, founder of Catholic for Free Choice, specifically asked me to speak from the Catholic theological viewpoint.

Based on what I said in the conference, I would like to now be bold and propose a way to make these Catholic arguments more comprehensible in the spirit of dialogue. The Catholic vision of bioethics is too often portrayed as a list of prohibitions. This is unfortunate. What I shared at the conference was an attempt to express some common points of departure on human sexuality and life issues. I spoke three possible areas where common denominator could be found to initiate dialogue: Reason, Love, and Freedom.

The ability to use reason is the basis for communication, dialogue, and debate. The Catholic Church believes firmly that there are truths that we can learn from science, from the observations of human nature and human actions. There is a law written in the very essence of nature that we could discover by human reason and is binding on who we are and how we ought to behave, known as the natural law [20]. Catholic teaching on bioethics therefore aims to be both reasoned and reasonable. If one takes an honest look at magisterial arguments on these issues, the starting point is never from the faith perspective but from rational reasoning. Hence, there is a possibility of dialogue with all people from different backgrounds and religions.

While the Church is not anti-science, it is against scientism which states that only empirical and observable data are true. As philosophers have argued thorough history, there are other ways to understand truths, such as the Aristotelian deduction of the existence of free will or the human soul, or the Thomistic proofs of God's existence, or the falsification of Popper, or Gödel's Incompleteness Theorom. That is, truth is not exclusive to scientific and empirical evidence [21]. As Pope John Paul II said in the encyclical Fides et Ratio, faith and reason do not contradict each other. Rather, they are like "two wings on which the human spirit rises to the contemplation of truth" [22]. During the conference, some pro-choice participants complained that Catholics were dominating the debate with their religious views. Rather surprisingly, Peter Singer came to the defense of the Catholic position as reason-based and not religiously based, and therefore form the basis of discussion. Otherwise, we are left with the position of Tristram Engelhardt who claims that we are all moral strangers where dialogue would be impossible [23].

The next common value for dialogue is love. Human beings want to love and be loved. Although with different convictions, both sides of the abortion debates hold their respective positions as manifestations of love. Pro-life groups see the unborn as a weak member of humanity that needs protection and love. Pro-choice groups want the woman to have the option to abort, as a loving response to difficult situations. Love is what we all seek, in our pursuit of happiness. However, we cannot leave out the question of sex from the question of love. Catholic teaching in this sense has a very demanding concept of love in sexuality, marriage and procreation. Are there real commitments in love, or is love just a feeling, a fleeting emotion? If love means commitment and responsibility, then we can deduce the demands of selflessness, exclusivity, durability and inseparability of the marital bond. We appreciate how love of a parent is not selfish, but opens up to sacrifice and self-giving. Ideally, love between man and woman would have a similar demand of commitment. Catholics would emphasize the point that man and woman love each other so much that it has a name-a new life. Love is diffusive, expansive and therefore creative and procreative. Nowadays, even some feminists are noticing how contraception can be anti-women, making men more irresponsible and treating women as objects of pleasure without the responsibility. There is overwhelming evidence that sex outside of marriage leads to higher rates of unwed pregnancy, abortion, poverty, and other miseries [24].

Recent popes have written bold words on sexuality. John Paul II spent the first five years of his pontificate during weekly catechesis to articulate and explain what is now known as the Theology of the Body [25]. Benedict XVI first encyclical was dedicated on love, in which he daringly attributes eros to the nature of God's passionate love. "Love is indeed ecstasy," the pontiff tells us, "but not in a hedonistic sense. If ecstasy means to go out of oneself," then love is ecstasy as "an ongoing exodus out of the closed inward-looking self towards its liberation through self-giving, and thus towards authentic self-discovery and indeed the discovery of God " [26]. Hence, strangely enough, a sincere discussion on what is the true meaning of love can be a basis of dialogue.

The third value that is shared by Christians and secularists alike is freedom. The Catholic Church is a strong defender of human freedom, because freedom corresponds to our human nature and dignity as a true image of God. Human beings are called to act freely and responsibly. Today, we are more aware of the need to be responsible in our lifestyle choices by avoiding drugs, alcohol, unhealthy food, etc. Wellbeing urges us to be responsible for our environment and food sources because there are consequences to these choices and actions. This proves that with freedom comes responsibility in all spheres of our lives, including our sexual behaviors. Postmodern culture is imbued with a demeaning presumption that we cannot control our sexual urges. Like animals, we are considered slaves to our instincts. But it is not true that people cannot control themselves. This would negate our freedom, in both senses of freedom-from and freedom-for. Rather, the Church teaches that education our human nature is essentially a free one, superior to those of animals, and thus through growth in virtues can help us overcome our passions and unhealthy tendencies, just like drug addicts and alcoholics can reform and regain their freedom. Sex in the proper context of a shared life should really free us, to make us more loving, noble, and human. Sadly, people often treat others as sex objects, given the rise of pornography, sex trafficking, prostitution, sexual abuses and rapes which are grave affronts against human dignity and freedom [27]

At the discussion after my presentation, one of the panelists who held a contrasting position recognized the sad state of today's sexual liberalization especially in the media and among the youth. She shared with the audience that talking to her teenage daughter about sex, she was surprised to hear her daughter state that she had decided to save 
her eggs for Mr. Right. If our minds and hearts are open to reason that rise above the mainstream chatter-truths about love, and truths about freedom-these can become the bases of conversation and dialogue.

\section{Challenges to Dialogue}

The challenges to dialogue are many and the road is arduous. As the Princeton conference shows, it was not easy at all to talk with those who think so differently from you. Most of the conversations that began there did not have much public follow-up. There does not seem to be a will to continue either among the organizers, speakers or participants. Of course the event may not have been meant to be an annual meeting, but to serve as a catalyst for learning and an introduction to the different dimensions, arguments, and facets inherent in the word abortion.

Similarly, the book by Australian writers on Common Ground did not generate much resonance. I met a pro-life advocate who wanted to burn this work as heresy. The State of Victoria passed new laws on abortions shortly after the book, ignoring most of the findings about what the public wants. There were just too many political interests at stake and ideological hurdles to overcome.

What this shows is that it requires a lot of courage to dialogue, to reach out to your opponent or the stranger, and accepting the risk to make mistakes. Perhaps it is a sign of maturity, both intellectual and spiritual, to engage in such endeavors. A few years ago, I was asked to write a piece on this subject and I was not prepared to stick out my neck for fears of misunderstanding or reprimands from pro-lifers and peers. Now, perhaps I am more cognizant of my debilities, and accept my limitations that I can be wrong. The words of Pope Francis in the interview are also encouraging in this regard:

This requires much humility, sacrifice and courage, especially when you are misunderstood or you are the subject of misunderstandings and slanders, but that is the most fruitful attitude... After all, in every age of history, humans try to understand and express themselves better. So human beings in time change the way they perceive themselves... Humans are in search of themselves, and, of course, in this search they can also make mistakes [28,29].

For those of us who believe that human life begins at conception, abortion must be resisted, but the person always embraced. Nevertheless, this does not imply a shunning of discussion with those who differ from us. Christian charity demands constant dialogue with those whom we disagree. We believe that reason and truth will prevail when there is sincerity and goodwill. For the alternative to reason and dialogue, as history has shown, often ends in injustices, violence and dominations [30].

\section{References}

1. See Antonio Spadaro "Intervista a Papa Francesco," La Civiltà Cattolica 2013 III 3918 (19 settembre 2013): 449-477. This was reprinted in English as "A Big Heart Open to God." America Staging.

2. Ibid.

3. http://www.cultura.va/content/cultura/en/dipartimenti/ateismo-e-non-credenza $\mathrm{html}$.

4. John Fleming and Nicholas Tonti-Filippini (2008) Common Ground? Seeking an Australian Consensus on Abortion and Sex Education.Strathfield, NSW: St. Pauls.

5. Of note, this is contrary to the finding in the survey that most people desire to have continual discussion on the subject based on accurate data. Of note, $71 \%$ Australians want more public discussion about abortion, and a surprising $76 \%$ believes that there should be equal participation of men and women.

6. Fleming and Tonti-Filippini, Common Ground, 45.
7. Fleming and Tonti-Filippini, Common Ground, 109.

8. See Benedict XVI (2009) Encyclical Letter Caritas in Veritate: On Intergal Human Development in Charity and Truth

9. See Joseph Ratzinger (2004) Truth and Tolerance: Christian Belief and World Religions. Ignatius Press, San Francisco, USA.

10. Although there could be uncertainties on many matters (1995) there are also certainties that can be known by natural reason and confirmed as definitive truth by the Church. In the case of abortion, there is no uncertainty in that "the direct and voluntary killing of an innocent human being is always gravely immoral." John Paul II, Encyclical Evangelium Vitae: On the Value and Inviolability of Human Life.

11. See "A Big Heart Open to God."

12. See Charles C Camosy (2012) Peter Singer and Christian Ethics: Beyond Polarization Peter Singer and Christian Ethics. Cambridge UnivPr.

13. See Daniel Callahan (2000) "Religion and Bioethics", Medical Ethics Newsletter [Lahey Hitchcock Clinic] (Winter 2000) 7.

14. Pope Francis, "A Big Heart Open to God."

15. See George Khushf, "Intolerant Tolerance," Journal of Medicine and Philosophy 19(2) 1994: 161-181.

16. Nigel Biggar (2011) Behaving in Public: How to Do Christian Ethics. Grand Rapids, Mich.: W.B. Eerdmans Pub. Co., 108.

17. I have been involved in some interreligious dialogue activities with the UNESCO Chair in Bioethics in Human Rights. Several conferences and workshops have been organized to engage bioethics expert from different religious backgrounds including Buddhism, all three branches of Christianity, Confucianism, Daoism Hinduism, Islam, and Judaism.

18. See Alasdair Maclntyre (1988) "Incommensurability, Truth and the Conversion between Confucians and Aristotelians about the virtues," in Culture and Modernity, 104-122; Id., Whose Justice? Which Rationality? Notre Dame: University of Notre Dame Press.

19. Maclntyre, “Incommensurability...," 118.

20. MacIntyre, "Incommensurability...," 119

21. http://uchv.princeton.edu/Life_Choice/

22. The question about nature is problematic today, as I said earlier. There is the challenge of the naturalistic fallacy that states from the "is" one cannot deduce the "ought." However, according to natural law theory, this theory of Hume and Moore does not apply since both the "is" and the "ought" comes from the same (human) nature. This law is written within the very nature of things that obliges nature to behave accordingly. This law written in nature is not positive law like manmade laws, which are prone to change. It is more similar to physical laws that we cannot disobey. This is discoverable by our reason of the way things "are" and the ways things "ought" to behave. So for instance, "murder is always wrong" is a truth that is universally discoverable in our conscience, as if it were a law written within of what is right and what is wrong, and how we ought to behave. See Elio Sgreccia, Manuele di Bioetica I, Vita e Pensiero, Milano 1999 49-51; Joseph Tham, "Natural Law and Global Bioethics," in Studia Bioethica 4.3(2011): 7-16; Pontifica Academia Pro Vita, Bioetica e Legge Naturale: Atti della Sedicesima Assemblea Generale dei membri, Città del Vaticano, 11-13 febbraio, 2010, (Rome: Lateran University Press) 2010.

23. See International Theological Commission, (2009) "In Search of a Universal Ethic: A New Look at the Natural Law".

24. See John Paul II, Encyclical Letter Fides Et Ratio: On The Relationship Between Faith and Reason, no.1

25. TristramEngelhardt $\mathrm{H}$ (1996) The Foundations of Bioethics. Oxford Univ. Press, New York, NY, USA.

26. See“It's Sex O'clock in America (2013) - CNN.com".

27. See John Paul II, Michael Waldstein (2006) Man and Woman He Created Them: a Theology of the Body. Pauline Books \& Media, Boston, MA, USA.

28. See Benedict XVI (2005) Encyclical Letter Deus Caritas Est: On Christian Love, 6.

29. See Karol Wojtyla (1993) Love and Responsibility. William Collins Son, London, New York, USA.

30. Pope Francis, "A Big Heart Open to God." 